Kroezen, M., Veer, A. de, Francke, A., Groenewegen, P., Dijk, L. van. Changes in nurses' views and practices concerning nurse prescribing between 2006 and 2012: results from two national surveys. Journal of Advanced Nursing: 2014, 70(11), 2550-2561

\begin{tabular}{|l|l|}
$\begin{array}{l}\text { Postprint } \\
\text { Version }\end{array}$ & 1.0 \\
\hline Journal website & $\underline{\text { http://onlinelibrary.wiley.com/doi/10.1111/jan.12404/full }}$ \\
\hline Pubmed link & $\underline{\text { http://www.ncbi.nlm.nih.gov/pubmed/24673626 }}$ \\
\hline DOI & $10.1111 / j a n .12404$ \\
\hline
\end{tabular}

This is a NIVEL certified Post Print, more info at http://www.nivel.eu

\title{
Changes in nurses' views and practices concerning nurse prescribing between 2006 and 2012: results from two national surveys
}

\author{
MARIEKE KRoEZEN MSC PHD RESEARCHER ${ }^{1, *}$, ANKE DE VEER PHD SENIOR \\ RESEARCHER/COORDINATOR NURSING STAFF PANEL ${ }^{1}$, ANNEKE FRANCKE PHD RN \\ Programme CoORdinator Nursing CARE ${ }^{1,2}$, Peter GroenEWEgen PHD NIVEL \\ DiRECTOR $^{1,3}$ AND LISET VAN DIJK PHD PROGRAMME COORDINATOR PHARMACEUTICAL \\ CARE $^{1}$
}

\begin{abstract}
Aims: To assess changes in the prescribing practices and views about nurse prescribing of Registered Nurses in the Netherlands between 2006 and 2012.

Background: Considering the developments that took place in the Netherlands between 2006 and 2012, such as increased opportunities for nurse prescribing education and stricter control of nurses' prescribing practices, this study examines the extent to which nurses' prescribing practices and views have changed in the intervening years. In both years, nurses were not legally allowed to prescribe.

Design: Survey study.

Methods: Surveys were conducted in 2006 and 2012. Questionnaires were sent to a national sample of nurses. The questionnaires addressed nurses' views on nurse prescribing and the extent to which nurse prescribing took place in the respondents' work setting.

Results: There were 386 and 644 respondents to the 2006 and 2012 surveys respectively. The proportion of nurses who said that they felt adequately equipped to prescribe medicines remained constant around $12 \%$. Insufficient knowledge to prescribe remained the most important reason for feelings of inadequacy. More than a quarter of the nurses in both surveys stated that nurses in their team sometimes write prescriptions. There were few changes in views on the consequences of nurse prescribing for nurses' practice.

Conclusion: Overall, nurses' support for nurse prescribing remained stable at a fairly cautious level, while the number of nurses feeling inadequately equipped to prescribe remained high. As nurse prescribing is expected to improve the quality and continuity of care, this should be taken into account in policy expectations.
\end{abstract}


Kroezen, M., Veer, A. de, Francke, A., Groenewegen, P., Dijk, L. van. Changes in nurses' views and practices concerning nurse prescribing between 2006 and 2012: results from two national surveys. Journal of Advanced Nursing: 2014, 70(11), 2550-2561

\section{Why is this research needed?}

- Nurse prescribing is being implemented in a growing number of countries.

- In the nursing profession, there is a debate about whether prescribing is something that nurses should be doing.

- It is unclear to what extent Registered nurses' prescribing practices and views are subject to change over the years.

\section{What are the key findings?}

- Between 2006 and 2012, the proportion of Dutch Registered Nurses who indicated that they felt adequately equipped to prescribe medicines remained constant around $12 \%$.

- The number of Registered Nurses who felt that the support from their organization was insufficient to prescribe increased between 2006 and 2012.

- Registered nurses' support for nurse prescribing remained stable at a fairly moderate level.

\section{How should the findings be used to influence policy/practice/research/education?}

- If part of the nursing profession has a reserved attitude towards nurse prescribing, expectations about the potential impact of nurse prescribing on health care may need to be adjusted.

- Large differences can arise between institutions when certain hospitals are supportive of nurse prescribing and others are not or less supportive.

\section{INTRODUCTION}

The number of countries where nurses are legally permitted to prescribe medication has grown considerably in recent decades (Aarts \& Koppel 2009, Drennan et al. 2009, Kroezen et al. 2011, 2012a). In 2014, specific categories of Registered Nurses (RNs) in the Netherlands will also be granted legal authority to prescribe medicines (Box 1). Much is expected of nurse prescribing in the current climate of cost containment in health care. In the UK, for example, it has been claimed that many of the quality targets set by the Department of Health for the primary care setting will rely on nurses taking on new roles (Nolan \& Bradley 2007) and in the Netherlands, nurse prescribing is being introduced to contribute to efficient and effective patient care and to improve the quality and continuity of care (Dutch House of Representatives 2011, Ministry of Health Welfare \& Sport 2011).

The implementation of healthcare policy in practice, in this case of nurse prescribing, is influenced by various factors, including healthcare professionals' individual attitudes (Currie et al. 2010). It is known that in the nursing profession, there is an ongoing debate about whether prescribing is something that nurses should be doing (Snowden 2008). Part of the nursing profession feels that nurse prescribing shifts the focus too much from care to cure and believes prescribing to be outside the parameters of nursing practice (Tye \& Ross 2000, McCann \& Baker 2002, Bradley et al. 2005, Bradley \& Nolan 2007). This is confirmed by research showing that the uptake of the nurse prescribing role can be variable (Nolan \& Bradley 2007). Moreover, while questions have been raised about whether nurses are sufficiently prepared for prescribing by current educational programmes (Bullock \& Manias 2002, Wilhelmsson \& Foldevi 2003, Banning 2004), other research has shown that nurses prescribe in comparable ways to physicians (Van Ruth et al. 2008) and that 
Kroezen, M., Veer, A. de, Francke, A., Groenewegen, P., Dijk, L. van. Changes in nurses' views and practices concerning nurse prescribing between 2006 and 2012: results from two national surveys. Journal of Advanced Nursing: 2014, 70(11), 2550-2561

educational programmes for nurse prescribing are operating largely satisfactorily (Latter et al. 2010).

Little is known about the extent to which nurses' attitudes towards nurse prescribing are being influenced by changes in policy and (increased) education possibilities and to what extent beliefs about what a nurse is and if and how prescribing fits into that role are steady over time. This is important to study, as the debate in nursing may have consequences for the intended effects of nurse prescribing as formulated by policymakers and professional associations. After all, if a large section of the nursing profession does not support the idea of nurse prescribing and does not make use of the authority to prescribe, this may lead to a significant gap between the actual and intended outcomes of nurse prescribing. In 2006, we performed a national survey among RNs in the Netherlands concerning their views on nurse prescribing and prescribing practices (De Veer et al. 2007b). To determine whether and how nurses' views and practices concerning nurse prescribing are subject to change over the years, we repeated our survey in 2012.

\section{[Box 1]}

\section{Background}

According to Abbott (1988), professional discussions about boundaries and task shifting, in this case concerning the prescribing of medicines, are shaped by various internal and external forces. Internal forces can be characterized as forces arising from within the professions themselves, whereas external forces relate to broader developments in society. An example of an internal force that may shape the professional discussion in nursing about prescribing rights is nurses' desire for more professional autonomy, whereas governmental striving for a more cost-effective healthcare system might be considered an external force.

In this paper, we compare Dutch nurses' views and practices concerning prescribing between 2006 and 2012. It should be noted that in 2006, Dutch RNs were not legally allowed to prescribe medicines, but it was well known that some RNs were already prescribing some medicines (Van der Peet 2010a,b, Kroezen et al. 2012b). Through the so-called 'extended arm' construction, physicians delegated the act of prescribing to nurses, but retained responsibility. In most cases, delegation only took place for a small number of relatively harmless medicines. Even though this practice took place by mutual consent between doctors and RNs, it was undesirable both legally and professionally (Roodbol 2006, Pool 2007), making it one of the main reasons for the forthcoming introduction of prescriptive authority for Dutch RNs (Van der Peet 2010a,b, Kroezen et al. 2012b). This sort of 'tolerance situation' is not uncommon in the Netherlands and can be found in other areas of practice as well (Kennedy 2002). Since 2006, developments took place that might have influenced RNs' views on nurse prescribing as well as their prescribing practices. Some external forces that might have shaped the professional debate in the Netherlands about nurse prescribing relate to the fact that nurse prescribing was introduced in two more European countries, Ireland and Finland and that several predominantly positive evaluations emerged from the UK and Ireland (Drennan et al. 2009, Latter et al. 2010). These events all generated positive attention from the Dutch nurses' Association (V\&VN) (Dutch nurses' Association 2011). More importantly, the new Dutch Medicines Act (Dutch: Geneesmiddelenwet) came into force on 1 July 2007 and the prescribing of medicines was added as a new reserved procedure to Section 36 of the Individual 
Kroezen, M., Veer, A. de, Francke, A., Groenewegen, P., Dijk, L. van. Changes in nurses' views and practices concerning nurse prescribing between 2006 and 2012: results from two national surveys. Journal of Advanced Nursing: 2014, 70(11), 2550-2561

Healthcare Professions Act (Dutch: Wet op de beroepen in de individuele nivel gezondheidszorg) (Van Meersbergen 2012). This created the legal opportunity to grant independent prescriptive authority to specific categories of nurses. However, to be able to actually prescribe medicines in practice, RNs still had to wait for the Ministerial Order to take effect that allocates prescriptive authority to specific categories of nurses. Nonetheless, the ensuing public debate about the introduction of nurse prescribing also drew growing attention to the existing illegal situation, resulting in increased monitoring of compliance with the rules by the Dutch Health Care Inspectorate (2006) and possibly making RNs more aware of the illegality of their prescribing practices at that time. The Ministerial Order that designated the first categories of RNs to be allowed to prescribe drugs was passed in 2012, but has not come into effect yet (see Box 1). Nonetheless, this means that unlike in 2006, when there was still much uncertainty about the particulars of the planned introduction of nurse prescribing, in 2012, all the legal and organizational details of RNs' prescriptive authority were known.

Forces arising from within the nursing profession itself might also have influenced the professional debate about nurse prescribing in recent years. Since 2006, nurse prescribing courses have been developed by several universities of applied sciences in the Netherlands and the Dutch nurses' Association has organized numerous information meetings about nurse prescribing. To examine whether these developments have changed nurses' practices and views concerning nurse prescribing, we compare RNs' prescribing practices and views in 2006 with their practices and views in 2012. We focus in particular on RNs' views concerning the influence of nurse prescribing on their workload, on the attractiveness of their work and on the opportunities for training and further development, as these aspects have a major impact on the potential uptake of nurse prescribing in practice.

\section{THE STUDY}

\section{Aim}

The aim of the study was to examine whether Dutch Registered nurses' prescribing practices and views changed between 2006 and 2012. The following research questions were addressed:

- Do RNs feel adequately equipped to prescribe medicines?

- How often and in what manner do RNs in nurses' work situations prescribe medicines?

- What are the views of RNs regarding the consequences of nurse prescribing for nurses' practice?

Based on the developments that took place in the Netherlands between 2006 and 2012 as described above - i.e. the increased opportunities for nurse prescribing education, the stricter control of nurses' prescribing practices pending the introduction of legal nurse prescribing and the increased information about the final form prescriptive authority would take - we formulated the following hypotheses: Hypothesis 1: RNs in 2012 feel better equipped to prescribe medicines than in 2006. Hypothesis 2: The number of RNs writing 'illegal' prescriptions in 2012 is smaller than in 2006.

Hypothesis 3: RNs hold more positive views on the consequences of nurse prescribing in 2012 compared with 2006. 
Kroezen, M., Veer, A. de, Francke, A., Groenewegen, P., Dijk, L. van. Changes in nurses' views and practices concerning nurse prescribing between 2006 and 2012: results from two national surveys. Journal of Advanced Nursing: 2014, 70(11), 2550-2561

\section{Design}

To answer our research questions, we conducted a national survey among RNs in the Netherlands in both 2006 and 2012.

\section{The instrument}

The survey questionnaire was developed by De Veer et al. (2007a) to measure whether nurses felt adequately equipped to prescribe medicines, what their views were on the intended changes to the legislation concerning nurse prescribing and whether nurses in their team were already prescribing medicines. For reasons of comparison, it was felt to be important that similar questions were asked in the 2012 survey. Hence, questions were posed in the same way and had the same answer categories in the 2012 survey as in the 2006 survey. A copy of the questionnaire is available from the first author.

The first part of the survey asked for general background information about respondents, including respondents' completed education, the type of institution where they were employed and whether they had undertaken or planned to take the 'Pharmacotherapy' module required for prescribing. Subsequently, survey questions addressed the extent to which nurse prescribing took place in the RNs' work setting, the extent to which RNs felt adequately equipped to prescribe medicines and their reasons for feeling thus and general views on nurse prescribing. The questions were predominantly multiple-choice, although there were also some open questions. Statements were positively and negatively worded to avoid response set bias. To prevent confusion, any potentially unknown terms were explained in the questionnaire.

\section{Participants}

Questionnaires were sent to members of the Nursing Staff Panel (Dutch: Panel Verpleging \& Verzorging) in 2006 and in 2012. The Nursing Staff Panel is a national sample that is representative of nursing staff in the largest healthcare sectors in the Netherlands, i.e. hospitals, mental health care, care for disabled people, home care, nursing homes and homes for the older people. The age and gender distribution of the panel members corresponds to the age and gender distribution of the Dutch nursing staff population. Participation is voluntary and anonymous. For our studies, all panel members who were RNs (in 2006, $n=500$; in 2012, $n=943$ ) were invited to participate in the survey. Until 1997, Dutch RNs were educated through in-service training. Currently, RNs are educated to two different levels: nurses educated to associate degree level (3-3.5 years of professional training, equivalent to a UK foundation qualification) and nurses educated to Bachelor's degree level (at least 4 years of professional training). Both levels are represented in the panel. It should be noted that when our study was conducted, none of the participating RNs had legal authority to prescribe medicines yet. Nurse specialists (with a Master's degree in Advanced Nursing Practice) were excluded from this study because their professional qualifications and associated prescriptive authority are different and regulated by a different article of law.

\section{Data collection}

In 2006, Nursing Staff Panel members received a first copy of the questionnaire, accompanied by a covering letter, by post. Reminders were sent 14 and 28 days later. In 2012, we used a mixed-mode survey approach. Members of the Nursing Staff Panel with a registered email address were initially contacted by email, but those 
Kroezen, M., Veer, A. de, Francke, A., Groenewegen, P., Dijk, L. van. Changes in nurses' views and practices concerning nurse prescribing between 2006 and 2012: results from two national surveys. Journal of Advanced Nursing: 2014, 70(11), 2550-2561

who failed to respond within 1 week and those without a registered email address were subsequently sent a first copy of the questionnaire, accompanied by a covering letter, by post. Afterwards, non-respondents received up to two reminders, approximately 14 and 28 days later.

\section{Ethical considerations}

The content of the questionnaire raised no substantial ethical issues. Study participation was voluntary and responses were anonymous and could not be traced to individual healthcare professionals, as was explained to participants in the covering letter that accompanied the questionnaire. Participant consent was assumed upon return of a completed questionnaire. Personal data were handled confidentially and processed anonymously as required by the rules of the Dutch Data Protection Act (Dutch: Wbp-Wet bescherming persoonsgegevens) and the applicable codes of conduct for scientific researchers.

\section{Data analysis}

As the Nursing Staff Panel is a rotating panel, there is some, but not complete, overlap between the 2006 sample and the 2012 sample. Hence, our samples cannot be considered completely independent or dependent. In our analyses, we controlled for clustering of respondents between both samples by using the Stata command 'vce'. This command computes standard errors that are robust to correlation. Descriptive analyses were used to compare the background characteristics of participants in 2006 and 2012. Whether nurses felt adequately equipped to prescribe medicines and their reasons for feeling thus were assessed using nine dichotomous items. Differences in percentage points between the 2006 and 2012 samples were tested for significance $(P \leq 0.05)$ using logistic regression, controlling for age and healthcare sector. Standard errors were corrected for clustering at the respondent level.

Eight dichotomous questions were asked to study how often nurses prescribed medicines and in what manner. RNs' views on the consequences of nurse prescribing for nurses' practice were assessed using three items on a 5-point Likert scale ranging from (1) “completely disagree'-(5) "completely agree'. Differences in percentage frequency of prescribing and mean scores for opinion items were calculated between the 2006 and 2012 samples and tested for significance $(P \leq 0 \cdot 05)$ using logistic regression, controlling for age and healthcare sector. Standard errors were corrected for clustering at the respondent level. Subgroup analyses were performed by grouping RNs according to their work setting/healthcare sector. Data were analysed using STATA version 12.1 (Statacorp, College Station, TX, USA, 2011). Additionally, we performed subgroup analyses for the 148 RNs who participated in both surveys (2006 and 2012). Their results corresponded with the overall results found and are therefore not presented separately in this paper.

\section{Validity and reliability}

The original survey questionnaire was developed based on the literature on nurse prescribing and the intended legislation. To enhance content validity, the questionnaire was reviewed by experts on nurse prescribing and adjustments were made on the basis of their feedback (De Veer et al. 2007a,b). 
Kroezen, M., Veer, A. de, Francke, A., Groenewegen, P., Dijk, L. van. Changes in nurses' views and practices concerning nurse prescribing between 2006 and 2012: results from two national surveys. Journal of Advanced Nursing: 2014, 70(11), 2550-2561

\section{RESULTS}

\section{Demographics}

Of the 500 questionnaires sent out in 2006, 386 were returned, yielding a response rate of $77 \cdot 2 \%$ (De Veer et al. 2007a,b). In 2012, the questionnaire was completed by 644 of the 943 panel members invited to take part, resulting in a slightly lower response rate of $68 \cdot 3 \%$. There is a $23 \%(n=148)$ overlap between the panel members surveyed in 2006 and those included in the 2012 survey. The gender breakdown of respondents is similar in the 2 years, with women outnumbering men in both surveys: 87.1\% and 83.9\% of respondents were female in the 2006 and 2012 surveys respectively. However, the respondents in the 2012 survey were on average somewhat older than the respondents in the 2006 survey, at $47 \cdot 2$ vs. $42 \cdot 4$ years and had more work experience: $21 \cdot 2$ vs. $17 \cdot 8$ years respectively (Table 1 ). This is partly explained by the ageing of the Dutch nursing profession as a whole. Furthermore, in 2012, a larger proportion of respondents worked in hospitals and nursing homes/homes for the elderly, while fewer respondents worked in the care for disabled people and home care (Table 1).

\section{[TABLE 1]}

\section{Feelings of being adequately equipped to prescribe medicines}

Only 12\% of the nurses surveyed in 2012 felt adequately equipped to prescribe medicines, a percentage equal to what we found in $2006(12 \cdot 7 \%)$. When it came to the reasons for nurses' feelings of being inadequately equipped to prescribe, hardly any changes have occurred since 2006 (Table 2). In both years, more than threefourth of all respondents said that they had insufficient knowledge to prescribe medicines, making it the most important reason for nurses' feelings of inadequacy. Interestingly, of the RNs who said that their knowledge was insufficient, $6 \%$ had already followed the 'Pharmacotherapy' module, $3.5 \%$ planned to do so within a year, while $90 \cdot 5 \%$ had no plans to follow the module at all. Moreover, $66 \cdot 7 \%(n=$ 26) of the RNs who had already followed the module still said that they had insufficient knowledge to prescribe (percentages not shown). The number of RNs who said that the support from their organization is insufficient to prescribe medicines has increased since 2006. In 2012, more than 40\% of the RNs felt a lack of support from their organization for nurse prescribing, whereas back in 2006, this was only $26 \%(P<0 \cdot 001)$.

\section{[TABLE 2]}

In other matters, no changes can be observed since 2006. As in 2006, we found that the second most important reason for nurses to feel inadequately equipped to prescribe medicines in 2012 was that formal responsibilities were not properly defined (61.6\%). Regarding the answers to the open response category 'other', most answers in 2006 and 2012 related to issues concerning professional task areas. Nurses stated, for example, that prescribing 'does not belong to nurses' task area' and 'should remain the sole domain of the doctor'.

Overall, we reject hypothesis 1, that RNs in 2012 feel better equipped to prescribe medicines than in 2006. Moreover, we conclude that hardly any changes have occurred in nurses' reasons for feelings of inadequacy in the intervening period. The 
Kroezen, M., Veer, A. de, Francke, A., Groenewegen, P., Dijk, L. van. Changes in nurses' views and practices concerning nurse prescribing between 2006 and 2012: results from two national surveys. Journal of Advanced Nursing: 2014, 70(11), 2550-2561

only change observed was that RNs feel less supported by their organization in 2012 in prescribing medicines than in 2006.

\section{Prescribing practices}

More than one-fourth of all RNs in our surveys stated that nurses in their team sometimes write prescriptions (Table 3). This percentage is slightly lower in 2012 $(27 \cdot 6 \%)$ than in $2006(29 \cdot 2 \%, P=0 \cdot 007)$. Subgroup analysis reveals that especially the number of RNs working in hospitals and home care who sometimes prescribe medicines has decreased since 2006. In 2012, hardly any RNs working in home care said that nurses in their team sometimes prescribe medicines (3.4\%) and less than half of the RNs working in hospitals said this (43.3\%). These numbers have declined by 11.6 percentage points and 20.9 percentage points, respectively, since 2006 ( $P=$ $0 \cdot 002)$. These results support hypothesis 2 , which states that the number of RNs writing 'illegal' prescriptions in 2012 is smaller than in 2006.

\section{[TABLE 3]}

If we look at the way nurses prescribe medicines, we find that overall, compared with 2006, fewer RNs said that prescribing takes place exclusively by order of the physician $(P=0 \cdot 041)$. By prescribing 'by order of the physician', we mean that a physician has determined which medicine a patient should receive and a nurse is asked, either in written or verbal form, to write the prescription. However, subgroup analysis shows that mental health care was the only sector where nurses prescribed medicines less often by order of the physician in 2012 (10 1\%) compared with 2006 (20.2\%; $P=0 \cdot 021)$. If nurses wrote medicines on their own initiative, these were usually for prescription-only medicines, either as repeat prescriptions $(3 \cdot 0 \%)$ or new prescriptions (9.0\%) and less often for pharmacy and over-the-counter medicines (3.0\%). There were no significant differences in this regard between 2006 and 2012.

\section{Views on the consequences of nurse prescribing for nurses' practice}

The number of RNs who had experience with RNs in their team writing prescriptions and who believed that nurse prescribing increases nurses' workload decreased from $69 \cdot 0 \%$ in 2006 to $53 \cdot 8 \%$ in $2012(P=0 \cdot 018)$. Despite this decrease, still more than half of RNs were concerned about work pressure issues in relation to nurse prescribing. Compared with in 2006, more RNs agreed that nurse prescribing makes nurses' work more interesting and that it offers possibilities for nurses to educate and develop themselves, but these increases were not significant (Table 4).

\section{[TABLE 4]}

We found partial support for hypothesis 3 that RNs hold more positive views on the consequences of nurse prescribing in 2012 compared with 2006. However, it should be noted that the percentages of RNs who hold positive views on the consequences of nurse prescribing for nurses' practice still lay in the region of $50-60 \%$.

\section{DISCUSSION}

In general, we found fairly little change in RNs views on prescribing and prescribing practices between 2006 and 2012. Based on the increased opportunities for nurse prescribing education and information meetings, we expected more RNs to feel adequately equipped to prescribe medicines, but this percentage remained constant (12.7\% in 2006 and $12 \cdot 0 \%$ in 2012). RNs' reasons for feeling thus were also stable, 
Kroezen, M., Veer, A. de, Francke, A., Groenewegen, P., Dijk, L. van. Changes in nurses' views and practices concerning nurse prescribing between 2006 and 2012: results from two national surveys. Journal of Advanced Nursing: 2014, 70(11), 2550-2561

with insufficient knowledge and no proper definition of formal responsibilities being the two most important ones. Moreover, we found that of the RNs who had already followed the 'Pharmacotherapy' module, a large majority still felt that they have insufficient knowledge to prescribe medicines. Unfortunately, our study does not provide information about why some of the RNs who followed the module still felt having insufficient knowledge to prescribe. Prior research has indicated that nurses' pharmacology knowledge and scientific education are insufficient to prescribe (Banning 2004, Latter et al. 2007). It has also been suggested that attention needs to be given to nurses' assessment and diagnostic skills, which underpin their prescribing role (Latter et al. 2010). After all, should RNs' basic educational preparation turn out to be insufficient to prescribe, the Pharmacotherapy module will not be sufficient to start prescribing in practice.

Remarkably, the percentage of RNs who felt the support from their organization to be insufficient increased to $40 \%$ in 2012 . As RNs are still not legally allowed to prescribe medicines, it is not surprising that four in 10 nurses still feel a lack of support from their organization, but the increase in comparison with 2006 is noteworthy. A possible explanation for this somewhat counterintuitive finding is that RNs, in anticipation of the forthcoming legislation, may have introduced the topic of nurse prescribing in their organizations and encountered a lack of enthusiasm and/or lack of the necessary preconditions for implementation that they were unaware of until then. This lack of organizational support, in terms of having structures and processes in place to enable nurse prescribing, is a frequently reported source of frustration and delay (Bradley et al. 2005, Stenner et al. 2010, Jones et al. 2011). Moreover, it has been found to seriously hamper the implementation of nurse prescribing across various countries (Chaston \& Seccombe 2009, Forchuk \& Kohr 2009).

In line with our expectations, the number of RNs indicating that nurses in their team sometimes write prescriptions was smaller in 2012 than in 2006, especially in hospitals and home care. This can be explained by the stricter controls by the Dutch Health Care Inspectorate in the intervening period and the possible subsequent reaction of healthcare organizations to this. Moreover, with all the media attention to forthcoming legislation, RNs themselves were also reminded of the fact that their prescribing practices at that time lacked a legal basis and this may have influenced their decision to do so. However, where RNs stated that RNs in their team did sometimes write prescriptions, this was less likely to involve prescribing exclusively by order of the physician. It is possible that the small group of RNs who were already prescribing were adjusting their prescribing practices in anticipation of the forthcoming legislation. Hence, there appear to be two different trends; one group of RNs has become more restrictive in view of the developments that took place between 2006 and 2012, while another group of RNs who continued to prescribe did so more often on their own initiative.

Finally, we expected RNs to hold more positive views on the consequences of nurse prescribing in 2012 compared with 2006, considering their increased knowledge about the final prescriptive authority they would be given and positive reviews from other countries that were highlighted by the Dutch nurses' Association, for example. The only significant difference found, however, was a decrease in the number of RNs who believed that nurse prescribing increases nurses' workload, from $69 \cdot 0 \%$ to a still relatively high $53 \cdot 8 \%$. 
Kroezen, M., Veer, A. de, Francke, A., Groenewegen, P., Dijk, L. van. Changes in nurses' views and practices concerning nurse prescribing between 2006 and 2012: results from two national surveys. Journal of Advanced Nursing: 2014, 70(11), 2550-2561

Hence, the prescribing views and practices of Dutch RNs changed little between 2006 and 2012, despite several internal and external forces that might have changed them. Our results suggest that external forces (developments from outside the nursing profession) such as the increased checks on illegal prescribing practices (Dutch Health Care Inspectorate 2006) had most, but still limited, influence. Overall, RNs' support for nurse prescribing and their actual prescribing practices and/or intention to prescribe remained subdued. The main explanation for this finding seems to lie in RNs' cautious attitude towards nurse prescribing. This is exemplified by the high percentage of RNs $(90.5 \%)$ in our study who have no plans to take the 'Pharmacotherapy' module that is required to obtain prescriptive authority. However, this result should be viewed in the context of the current legislation. Prescriptive authority will initially only be assigned to three categories of RNs, namely: diabetes, lung and oncology nurses. Other categories of RNs may therefore feel little need as yet to take the module. Nonetheless, several professional associations of other categories of specialized RNs have already indicated to the Ministry of Health that they would like to apply for prescriptive authority as well, including prison nurses, dialysis and nephrology nurses, rheumatology nurses, community psychiatric nurses and HIV/AIDS nurses (Ministry of Health Welfare \& Sport 2013, Nursing 2013). In view of this, the $90 \cdot 5 \%$ of RNs who have no plans to take the 'Pharmacotherapy' module can still be considered quite high.

Our study showed that RNs' views and practices concerning nurse prescribing are fairly stable. Internal and external forces, including increased educational opportunities, have fairly limited influence on their views and practices. This suggests that prescribing touches on a fundamental issue in nursing, namely what constitutes nursing practice. Part of the nursing profession feels that nurse prescribing shifts the focus too much from care to cure and believes prescribing to be outside the parameters of nursing practice (Tye \& Ross 2000, McCann \& Baker 2002, Bradley et al. 2005, Bradley \& Nolan 2007). Our study contributes to existing knowledge by suggesting that this is a fairly steady position. If, as our results suggest, part of the nursing profession has a reserved attitude towards nurse prescribing and a considerable number of RNs experience a lack of support from their organization for nurse prescribing, expectations about the potential impact of nurse prescribing on health care may need to be adjusted. After all, introducing the legal possibility of nurse prescribing does not automatically lead to actual nurse prescribing in practice. If a substantial proportion of RNs do not use their authority to prescribe, positive effects may be lower than expected and/or hoped for. It has already been shown that the uptake of the nurse prescribing role can be variable (Nolan \& Bradley 2007). However, internationally little is known yet about how many nurses actually make use of the ability to prescribe and if they do so, how often they prescribe in daily practice. As much policy is based on the assumption of a positive uptake and active use of prescriptive authority, it is important to gain more insight into these matters.

\section{Limitations}

Several limitations of the study bear mentioning. Even though we had a fairly good overall response rate and sample size for analyses for the 2006 and 2012 surveys, the nature of our questionnaire meant that some analyses could be performed on only a small number of respondents, which led to a lack of statistical power and prevents us from drawing any definitive conclusions. Moreover, we were unable to perform 
Kroezen, M., Veer, A. de, Francke, A., Groenewegen, P., Dijk, L. van. Changes in nurses' views and practices concerning nurse prescribing between 2006 and 2012: results from two national surveys. Journal of Advanced Nursing: 2014, 70(11), 2550-2561

subgroup analysis for the three groups of RNs who will initially be granted prescribing rights in the Netherlands (i.e. diabetes care, lung and oncology nurses) for two reasons: first, in 2006, there was no question about nursing specialization, hence we were unable to determine which nurses among the respondents fell into one of these categories and second, in 2012, their numbers were too small $(n=19)$. However, some descriptive analyses show that only four of these 19 RNs felt adequately equipped to prescribe medicines. Moreover, even though they were encouraged by their professional associations to already take the 'Pharmacotherapy' module, only seven of the 19 RNs had done so or had plans to do so, while 12 of the 19 RNs said that they had no plans in this direction. Hence, these results appear to be in agreement with the overall results found. Finally, because we asked respondents to report on prescribing practices that were still illegal, we asked how often nurses in their team wrote prescriptions instead of how often they themselves wrote prescriptions. While this may have lowered the chances of obtaining socially desirable responses, it is also a less accurate way of measuring nurses' prescribing practices.

\section{CONCLUSION}

The findings of this study highlight the persistency of the international debate in the nursing profession about whether prescribing is something that nurses should be doing. If part of the nursing profession has a reserved attitude towards nurse prescribing, policy expectations about the potential impact of nurse prescribing on health care may need to be adjusted. In-depth qualitative research should further explore why some of the RNs in our sample who already followed the required prescribing training still felt to have insufficient knowledge to prescribe. To ensure that nurse prescribing constitutes a safe and high-quality practice, it is important that educational curricula fit RNs' needs. Finally, a study amongst nurses, physicians and managers at organizational level would be valuable in exploring barriers and facilitators to the implementation of nurse prescribing in everyday practice. Results of such a study could be used, for example, by nursing and medical associations, to help organizations adapt to nurse prescribing.

\section{Funding}

This study was funded by a grant to NIVEL from the Dutch Ministry of Education, Culture and Science. The Nursing Staff Panel is financed by the Dutch Ministry of Health, Welfare and Sport.

\section{Conflict of interest}

No conflict of interest has been declared by the authors.

\section{Author contributions}

The authors have confirmed that all authors meet the ICMJE criteria for authorship credit (www.icmje.org/ethical_1author.html), as follows:

- substantial contributions to conception and design of, or acquisition of data or analysis and interpretation of data,

- drafting the article or revising it critically for important intellectual content, and

- final approval of the version to be published. 
Kroezen, M., Veer, A. de, Francke, A., Groenewegen, P., Dijk, L. van. Changes in nurses' views and practices concerning nurse prescribing between 2006 and 2012: results from two national surveys. Journal of Advanced Nursing: 2014, 70(11), 2550-2561

\section{REFERENCES}

Aarts J. \& Koppel R. (2009) Implementation of computerized physician order entry in seven countries. Health Affairs 28(2), 404-414.

Abbott A. (1988) The System of Professions: An Essay on the Division of Expert Labor. The University of Chicago Press, Chicago, IL.

Banning M. (2004) Nurse prescribing, nurse education and related research in the United Kingdom: a review of the literature. Nurse Education Today 24, 420-427.

Bradley E. \& Nolan P. (2007) Impact of nurse prescribing: a qualitative study. Nursing 59(2), 120-128.

Bradley E., Campbell P. \& Nolan P. (2005) Nurse prescribers: who are they and how do they perceive their role? Journal of Advanced Nursing 51(5), 439-448.

Bullock S. \& Manias E. (2002) The educational preparation of undergraduate nursing students in pharmacology: a survey of lecturers' perceptions and experiences. Journal of Advanced Nursing 40, 7-16.

Chaston D. \& Seccombe J. (2009) Mental health nurse prescribing in New Zealand and the United kingdom: comparing the pathways. Perspectives in Psychiatric Care 45(1), 17-23.

Currie G., Finn R. \& Martin G. (2010) Role transition and the interaction of relational and social identity: new nursing roles in the English NHS. Organization Studies 31(7), 941-961.

De Veer A.J.E., Francke A.L., Poortvliet E.P. \& Verkerk M. (2007a) Voorschrijven van medicatie door verpleegkundigen. Factsheet Panel Verpleegkundigen en Verzorgenden [Prescribing of medicines by nurses. Factsheet Nursing Staff Panel]. NIVEL, Utrecht.

De Veer A.J.E., Francke A.L., Poortvliet E.P. \& Verkerk M. (2007b) Wensen en verwachtingen van verpleegkundigen bij het voorschrijven van medicatie. Factsheet Panel Verpleegkundigen en Verzorgenden [Wishes and expectations of nurses concerning the prescribing of medicines. Factsheet Nursing Staff Panel]. NIVEL, Utrecht.

Drennan J., Naughton C., Allen D., Hyde A., Felle P., O'Boyle K., Treacy P. \& Butler M. (2009) National Independent Evaluation of the Nurse and Midwife Prescribing Initiative. University College Dublin, Dublin.

Dutch Health Care Inspectorate (2006) Circulaire Taakherschikking en voorschrijven geneesmiddelen [Ciruclar Task reallocation and prescribing of medicines]. Inspectie voor de Gezondheidszorg, Den Haag.

Dutch House of Representatives (2011) Tweede Kamer der Staten-Generaal, vergaderjaar 2010-2011, 32 196, 32 261, nr. 13, Brief van de Minister van Volksgezondheid, Welzijn en Sport [The Dutch House of Representatives, year 2010-2011, 32 196, 32 261, no. 13, Letter of the Minister of Health, Welfare and Sport]. Tweede Kamer der Staten-Generaal, Den Haag.

Dutch nurses' Association (2011) Finse verpleegkundigen mogen voorschrijven [Finnish nurses are allowed to prescribe]. Retrieved from http://www.venvn.nl/Actueel/Nieuwsarchief/tabid/1789/Articleid/4313/mid/3452/Default.aspx on 18 November 2013.

EADV (2013) Positief nieuws voorschrijfbevoegdheid [Positive news prescriptive authority]. Retrieved from http://www.eadv.nl/page/Actueel/Nieuws?mod[427][article_id]=283 on 18 November 2013.

Fontys University of Applied Sciences (2013) Farmacotherapie voor verpleegkundigen [Pharmacotherapy for nurses]. Retrieved from https://fontys.nl/Over-Fontys/FontysHogeschool-Verpleegkunde-2/Nieuws-tonen-op/Farmacotherapie-voorverpleegkundigen.htm on 18 November 2013.

Forchuk C. \& Kohr R. (2009) Prescriptive authority for nurses: the Canadian perspective. Perspectives in Psychiatric Care 45(1), 3-8.

Jones K., Edwards M. \& While A. (2011) Nurse prescribing roles in acute care: an evaluative case study. Journal of Advanced Nursing 67(1), 117-126.

Kennedy J. (2002) Een weloverwogen dood [A Deliberate Death]. Bert Bakker, Amsterdam. Kroezen M., Van Dijk L., Groenewegen P.P. \& Francke A.L. (2011) Nurse prescribing of medicines in Western European and Anglo-Saxon countries: a systematic review of the literature. BMC Health Services Research 11, 127. 
Kroezen, M., Veer, A. de, Francke, A., Groenewegen, P., Dijk, L. van. Changes in nurses' views and practices concerning nurse prescribing between 2006 and 2012: results from two national surveys. Journal of Advanced Nursing: 2014, 70(11), 2550-2561

Kroezen M., Francke A.L., Groenewegen P.P. \& Van Dijk L. (2012a) Nurse prescribing of medicines in Western European and Anglo-Saxon countries: a survey on forces, conditions and jurisdictional control. International Journal of Nursing Studies 49(8), 1002-1012.

Kroezen M., Francke A.L., Groenewegen P.P. \& Van Dijk L. (2012b) Voorschrijfbevoegdheid voor verpleegkundigen: visies en verwachtingen van Nederlandse stakeholders [Nurse prescribing: views and expectations of Dutch stakeholders]. Verpleegkunde 2, 10-16.

Latter S., Maben J., Myall M. \& Young A. (2007) Perceptions and practice of concordance in nurses' prescribing consultations: findings from a national questionnaire survey and case studies of practice in England. International Journal of Nursing Studies 44(1), 9-18.

Latter S., Blenkinsopp A., Smith A., Chapman S., Tinelli M., Gerard K., Little P., Celino N., Granby T., Nicholls P. \& Dorer G. (2010) Evaluation of Nurse and Pharmacist Independent Prescribing. Department of Health, London.

McCann T.V. \& Baker H. (2002) Community mental health nurses and authority to prescribe medications: the way forward? Journal of Psychiatric and Mental Health Nursing 9(2), 175182.

Ministry of Health Welfare and Sport (2011) Besluit van 21 December 2011, houdende tijdelijke regels inzake de zelfstandige bevoegdheid tot het verrichten van voorbehouden handelingen van verpleegkundig specialisten (Tijdelijk besluit zelfstandige bevoegdheid verpleegkundig specialisten) [Decision of 21 December, on temporary rules relating to the autonomous power to perform restricted actions of nurse specialists (Temporary autonomous decision power nurse specialists)]. Staatsblad van het Koninkrijk der Nederlanden 659, Ministerie van Volksgezondheid, Welzijn en Sport, Den Haag.

Ministry of Health Welfare and Sport (2012) Regeling van de Minister van Volksgezondheid, Welzijn en Sport, van MEVA/BOA-3109304, houdende het voorschrijven van URgeneesmiddelen door bepaalde categorieen van verpleegkundigen [Regulation of the Ministry of Health, Welfare and Sport, of MEVA/BOA-3109304, containg the prescribing of prescription only- medicines by certain categories of nurses]. Ministerie van Volksgezondheid, Welzijn en Sport, Den Haag.

Ministry of Health Welfare and Sport (2013) Beantwoording vso regeling houdende het voorschrijven van UR-geneesmiddelen door bepaalde categorieen van verpleegkundigen [Answering vso procedure involving the prescribing of POMs by certain categories of nurses]. Ministerie van Volksgezondheid, Welzijn en Sport, Den Haag.

Nolan P. \& Bradley E. (2007) The role of the nurse prescriber: the views of mental health and non-mental health nurses. Journal of Psychiatric and Mental Health Nursing 14(3), 258-266.

Nursing (2013) More nurses want to prescribe medicines [Meer verpleegkundigen willen medicatie voorschrijven]. Retrieved from

www.nursing.nl/Verpleegkundigen/Nieuws/2013/4/Meer-verpleegkundigen-willenmedicatie-voorschrijven-1241036W/ on 18 Nov-ember 2013.

Overheid.nl (2013) Wet op de beroepen in de individuele gezondheidszorg. Geldend op 2301-2013 [Individual Health Care Professions Act. Applicable on 23-01-2013]. Retrieved from http://wetten.overheid.nl/BWBR0006251/geldigheidsdatum_23-01-2013 on 18 November 2013.

Pool A. (2007) Gedeelde verantwoordelijkheid en professionele aansprakelijkheid [Shared responsibility and professional liability]. Onderwijs en gezondheidszorg 4, 11-15.

Roodbol P.F. (2006) Nurse practitioners in Nederland: wat hangt de huisarts boven het hoofd? Huisarts en Wetenschap 49, 451-454.

Rotterdam University of Applied Sciences (2013) Farmacotherapie voor Longverpleegkundigen [Pharmacotherapy for Lung nurses]. Retrieved from http://www.transfergroep.nl/nl/Opleidingen/Gezondheidszorg/Farmacotherapie-voorlongverpleegkundigen/ on 18 November 2013.

Snowden A. (2008) Quantitative analysis of mental health nurse prescribers in Scotland. Journal of Psychiatric and Mental Health Nursing 15, 471-478.

Stenner K., Carey N. \& Courtenay M. (2010) Implementing nurse prescribing: a case study in diabetes. Journal of Advanced Nursing 66(3), 522-531.

Tye C.C. \& Ross F.M. (2000) Blurring boundaries: professional perspectives of the emergency nurse practitioner role in a major accident and emergency department. Journal of Advanced Nursing 31(5), 1089-1096. 
Kroezen, M., Veer, A. de, Francke, A., Groenewegen, P., Dijk, L. van. Changes in nurses' views and practices concerning nurse prescribing between 2006 and 2012: results from two national surveys. Journal of Advanced Nursing: 2014, 70(11), 2550-2561

Van der Peet R. (2010a) De voorschrijfbevoegdheid van verpleegkundigen [The prescriptive authority of nurses]. Tijdschrift voor Verpleegkundigen 120(7/8), 50-53.

Van der Peet R. (2010b) De zelfstandige bevoegdheid van de verpleegkundig specialist [The independent authority of the nurse specialist]. Tijdschrift voor Verpleegkundigen 120(7/8), 45-49.

Van Meersbergen D.Y.A. (2012) De veranderde positie van de verpleegkundige in de Wet BIG [The changed position of the nurse in the BIG Act]. Tijdschrift voor Gezondheidsrecht 36(3), 203-217.

Van Ruth L., Francke A.L. \& Mistiaen P. (2008) Effects of nurse prescribing of medication: a systematic review. Internet Journal of Healthcare Administration 5(2). doi:10.5580/11e.

Wilhelmsson S. \& Foldevi M. (2003) Exploring views on Swedish district nurses' prescribing a focus group study in primary health care. Journal of Clinical Nursing 12(5), 643-650.

\section{TABLES AND BOX}

Box 1. Nurse prescribing for specific categories of RNs in the Netherlands as per November 2013

- Section 36 (14) of the Individual Healthcare Professions Act states that the authority to prescribe prescription-only medicines can be granted to specific categories of RNs that are designated by a Ministerial Order.

- Categories of RNs designated by Ministerial Order as authorized to prescribe prescription-only medicines are only allowed to prescribe after a diagnosis has been made by a doctor (Ministry of Health Welfare \& Sport 2012, Overheid.nl 2013). - Categories of RNs designated by Ministerial Order as authorized to prescribe prescription-only medicines can only prescribe a limited number of medicines within their specialism as specified in protocols and standards (Ministry of Health Welfare \& Sport 2012, Overheid.nl 2013).

- The categories of RNs that are initially designated by Ministerial Order as authorized to prescribe medicines are diabetes care nurses, lung nurses and oncology nurses (Ministry of Health Welfare \& Sport 2012). However, this Ministerial Order has not yet taken effect. In future, the Minister of Health can assign prescriptive authority to further categories of RNs by Ministerial Order.

- To be allowed to prescribe, RNs who fall in one of the designated categories must hold a Bachelor's degree and they must have successfully completed a Pharmacotherapy module at a university of applied sciences. Universities of applied science are responsible for the content of this module and they must ask the Dutch Ministry of Health for approval. Most Pharmacotherapy modules consist of a 3-day training, with a total study time of approximately 70 hours. Costs are paid either by the nurse or employer and vary from 650 to 925 euros, depending on educational institution. To be allowed into the Pharmacotherapy module, RNs must have successfully completed nursing education at Bachelor degree level, be registered as a nurse in the BIG register, have at least 2 years of relevant clinical nursing experience, have a training place and supervisor in their work environment and work at least 18 hours a week as RN. The content of the module is fairly similar across all educational institutions, including: legislation on nurse prescribing, pharmacokinetics, pharmacodynamics, models for choosing and prescribing medicines, ethical aspects, medication adherence, patient perspective and medication safety (e.g. Fontys University of Applied Sciences 2013, Rotterdam University of Applied Sciences 2013). 
Kroezen, M., Veer, A. de, Francke, A., Groenewegen, P., Dijk, L. van. Changes in nurses' views/ and practices concerning nurse prescribing between 2006 and 2012: results from two national surveys. Journal of Advanced Nursing: 2014, 70(11), 2550-2561

- It is expected that diabetes care and lung nurses will be authorized to start prescribing by February 2014 and oncology nurses by September 2014 (EADV 2013).

Table 1. Demographic characteristics of respondents 2006 and 2012.

\begin{tabular}{|c|c|c|c|c|}
\hline & 2006 & 2012 & $\begin{array}{c}\text { Test } F \\
\text { statistic }\end{array}$ & $P$-value \\
\hline Total $n$ for analyses & 386 & 644 & & \\
\hline \begin{tabular}{|l|} 
Respondents in both 2006 and 2012 \\
surveys (\% of total per survey)
\end{tabular} & $148(38 \cdot 3 \%)$ & || $148(23 \cdot 0 \%)$ & & \\
\hline Female $^{\mathrm{b}}$ & $87 \cdot 1 \%$ & $83 \cdot 9 \%$ & & $0 \cdot 105 c$ \\
\hline Mean (range) age in years ${ }^{\mathrm{b}}$ & $42 \cdot 4(23 \cdot 0-61 \cdot 0)$ & $47 \cdot 2(22 \cdot 0-65 \cdot 7)$ & $74 \cdot 81$ & $<0 \cdot 001^{\mathrm{a}, \mathrm{d}}$ \\
\hline $\begin{array}{l}\text { Mean number of years' work } \\
\text { experience, }\end{array}$ & $17 \cdot 8(n=382)$ & $21 \cdot 2(n=639)$ & $37 \cdot 77$ & $<0 \cdot 001^{\mathrm{a}, \mathrm{d}}$ \\
\hline $\begin{array}{l}\text { Respondents working in hospital } \\
\text { care }\end{array}$ & 96 (24·9\%) & $261(40 \cdot 5 \%)$ & & \\
\hline $\begin{array}{l}\text { Respondents working in mental } \\
\text { health care }\end{array}$ & $96(24 \cdot 9 \%)$ & || $130(20 \cdot 2 \%)$ & & \\
\hline $\begin{array}{l}\text { Respondents working in care for } \\
\text { disabled people }^{\mathrm{d}}\end{array}$ & (91 (23.5\%) & $90(14 \cdot 0 \%)$ & & \\
\hline Respondents working in home care & $100(25 \cdot 9 \%)$ & $118(18 \cdot 3 \%)$ & & \\
\hline $\begin{array}{l}\text { Respondents working in nursing } \\
\text { homes or homes for the elderly }\end{array}$ & $3(0 \cdot 8 \%)$ & $45(7 \cdot 0 \%)$ & & \\
\hline $\begin{array}{l}\text { Respondents belonging to one of } \\
\text { the first categories of specialized } \\
\text { RNs to be granted prescribing } \\
\text { rights (i.e. diabetes care nurses, } \\
\text { lung nurses and oncology nurses) }\end{array}$ & Not asked & $\mid 19(3 \cdot 0 \%)$ & & \\
\hline
\end{tabular}

$$
{ }^{\mathrm{a}} P<0 \cdot 001 .
$$

${ }^{\mathrm{b}}$ Standard errors are corrected for clustering at the respondent level.

c Significance levels derive from logistic regression analysis.

${ }^{\mathrm{d}}$ Significance levels derive from linear regression analysis.

${ }^{\mathrm{e}}$ Has missing values. 
Kroezen, M., Veer, A. de, Francke, A., Groenewegen, P., Dijk, L. van. Changes in nurses' views and practices concerning nurse prescribing between 2006 and 2012: results from two national surveys. Journal of Advanced Nursing: 2014, 70(11), 2550-2561

Table 2. Reasons RNs do not feel adequately equipped to prescribe medicines ${ }^{\mathrm{b}}$

\begin{tabular}{|c|c|c|c|}
\hline & $n$ & $\%$ & $P$-value \\
\hline \multicolumn{4}{|c|}{ My knowledge is insufficient } \\
\hline 2006 & 269 & $82 \cdot 8$ & \multirow{2}{*}{$0 \cdot 579$} \\
\hline 2012 & 431 & $77 \cdot 0$ & \\
\hline \multicolumn{4}{|c|}{ Formal responsibilities are not properly defined } \\
\hline 2006 & 202 & $62 \cdot 2$ & \multirow{2}{*}{$0 \cdot 886$} \\
\hline 2012 & 345 & $61 \cdot 6$ & \\
\hline \multicolumn{4}{|c|}{ The division of tasks between doctors and nurses is not properly defined } \\
\hline 2006 & 136 & $41 \cdot 9$ & \multirow{2}{*}{$0 \cdot 193$} \\
\hline 2012 & 213 & $38 \cdot 0$ & \\
\hline \multicolumn{4}{|c|}{ The support from my organization is insufficient } \\
\hline 2006 & 85 & $26 \cdot 2$ & \multirow{2}{*}{$<0 \cdot 001^{\mathrm{a}}$} \\
\hline 2012 & 225 & $40 \cdot 2$ & \\
\hline \multicolumn{4}{|c|}{ My skills are insufficient } \\
\hline 2006 & 72 & $22 \cdot 2$ & \multirow{2}{*}{$0 \cdot 302$} \\
\hline 2012 & 140 & $25 \cdot 0$ & \\
\hline \multicolumn{4}{|c|}{ I have too little time to do it } \\
\hline 2006 & 33 & $10 \cdot 2$ & \multirow{2}{*}{$0 \cdot 103$} \\
\hline 2012 & 74 & $13 \cdot 2$ & \\
\hline \multicolumn{4}{|l|}{ Other } \\
\hline 2006 & 38 & $11 \cdot 7$ & \multirow{2}{*}{$0 \cdot 456$} \\
\hline 2012 & 76 & $13 \cdot 6$ & \\
\hline
\end{tabular}

${ }^{b}$ Significance levels derive from logistic regression analyses that controlled for age and healthcare sector. Standard errors are corrected for clustering at the respondent level.

These questions were only answered by nurses who said that they did not feel adequately equipped to prescribe medicines. 
Kroezen, M., Veer, A. de, Francke, A., Groenewegen, P., Dijk, L. van. Changes in nurses' views and practices concerning nurse prescribing between 2006 and 2012: results from two national

Table 3. nurses' prescribing practices ${ }^{\mathrm{b}}$.

\begin{tabular}{|c|c|c|c|}
\hline $\begin{array}{c}\text { Nurses in } \\
\text { my team... }\end{array}$ & $N$ & $\%$ & $P$-value \\
\hline \multicolumn{4}{|c|}{$\begin{array}{l}\text { Sometimes prescribe medicines (apart from the question who signs the } \\
\text { prescription) }\end{array}$} \\
\hline 2006 & 112 & $29 \cdot 2$ & \multirow{2}{*}{$0 \cdot 007^{\mathrm{a}}$} \\
\hline 2012 & 177 & $27 \cdot 6$ & \\
\hline \multicolumn{4}{|c|}{ Prescribe exclusively by order of the physician } \\
\hline 2006 & 65 & $17 \cdot 0$ & \multirow{2}{*}{$0 \cdot 041^{\mathrm{a}}$} \\
\hline 2012 & 81 & $12 \cdot 7$ & \\
\hline \multicolumn{4}{|c|}{ Sometimes prescribe on their own initiative } \\
\hline 2006 & 46 & $12 \cdot 0$ & \multirow{2}{*}{$0 \cdot 041^{\mathrm{a}}$} \\
\hline 2012 & 93 & $14 \cdot 6$ & \\
\hline \multicolumn{4}{|c|}{$\begin{array}{l}\text { Sometimes prescribe on their own initiative, but only pharmacy and over-the- } \\
\text { counter medicines }\end{array}$} \\
\hline 2006 & 13 & $3 \cdot 4$ & \multirow{2}{*}{$0 \cdot 116$} \\
\hline 2012 & 19 & $3 \cdot 0$ & \\
\hline \multicolumn{4}{|c|}{$\begin{array}{l}\text { Sometimes prescribe prescription-only medicines on their own initiative, but onl } \\
\text { for repeat prescriptions }\end{array}$} \\
\hline 2006 & 6 & $1 \cdot 6$ & \multirow{2}{*}{$0 \cdot 324$} \\
\hline 2012 & 19 & $3 \cdot 0$ & \\
\hline \multicolumn{4}{|c|}{$\begin{array}{l}\text { Sometimes prescribe new prescriptions for prescription-only medicines on their } \\
\text { own initiative }\end{array}$} \\
\hline 2006 & 26 & $6 \cdot 8$ & \multirow{2}{*}{$0 \cdot 324$} \\
\hline 2012 & 58 & $9 \cdot 0$ & \\
\hline
\end{tabular}

${ }^{a} P<0 \cdot 05$.

${ }^{b}$ Significance levels derive from logistic regression analyses that controlled for age and healthcare sector. Standard errors are corrected for clustering at the respondent level. $n$ (\%), number of RNs who answered 'yes' to the question. 
Kroezen, M., Veer, A. de, Francke, A., Groenewegen, P., Dijk, L. van. Changes in nurses' views and practices concerning nurse prescribing between 2006 and 2012: results from two national surveys. Journal of Advanced Nursing: 2014, 70(11), 2550-2561

Table 4. nurses' views on consequences of nurse prescribing for nurses' practice ${ }^{\mathrm{b}}$.

\begin{tabular}{||l|l|l|l||}
\hline \multicolumn{1}{|c|}{ Nurse prescribing... } & \% of RNs who (totally) agree & \multirow{2}{*}{ P-value } \\
\cline { 2 - 3 } & $\mathbf{2 0 0 6}(\boldsymbol{n}=\mathbf{2 9})$ & $\mathbf{2 0 1 2}(\boldsymbol{n}=\mathbf{9 3})$ & \\
\hline Increases nurses' workload & $69 \cdot 0$ & $53 \cdot 8$ & $0 \cdot 018^{\mathrm{a}}$ \\
\hline \hline Makes nurses' work more interesting & $51 \cdot 7$ & $62 \cdot 4$ & $0 \cdot 457$ \\
\hline \hline $\begin{array}{l}\text { Offers possibilities for nurses to educate and } \\
\text { develop themselves }\end{array}$ & $41 \cdot 4$ & $47 \cdot 3$ & $0 \cdot 527$ \\
\hline \hline
\end{tabular}

${ }^{\mathrm{a}} \mathrm{P}<0 \cdot 05$.

${ }^{\mathrm{b}}$ Significance levels derive from linear regression analyses that controlled for age and healthcare sector. Standard errors are corrected for clustering at the respondent level.

This question was only answered by nurses who indicated that nurses in their team sometimes write prescriptions on their own initiative. Scores on the items varied from 1 (totally disagree) to 5 (totally agree). 